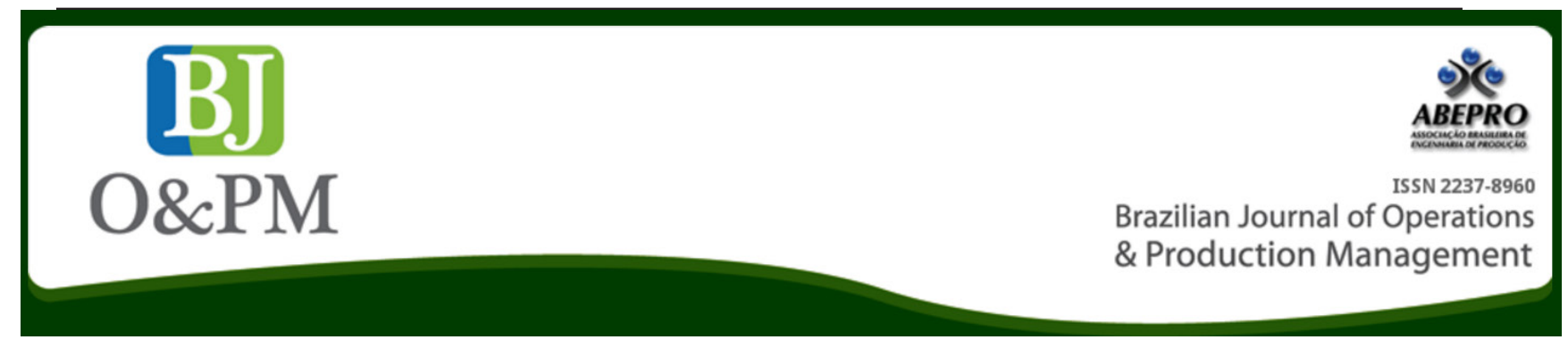

\title{
USING THE SERVQUAL MODEL TO ASSESS MALL SERVICE QUALITY AND CUSTOMER SATISFACTION
}

Larissa Maria Argollo de Arruda Falcão; Taciana de Barros Jerônimoa; Fagner José Coutinho de Meloa; Joas Tomaz de Aquino ; Denise Dumke de Medeiros ${ }^{a}$

${ }^{\text {a }}$ Federal University of Pernambuco (UFPE) - Recife, PE, Brazil

\section{ABSTRACT}

This paper uses SERVQUAL measure for assessing the quality of the administrative services in a large mall, located in Brazil, seen from the point of view of the current service providers. A questionnaire was used to interview 68 service companies, and 5 CEO mall of this case of study. Two factors were compared: the expectations and perceptions of the service providers, the comparison enabled the strengths and weaknesses of the quality perceived of the services offered by the mall were undertaken as a case study. It is necessary to understand which features and level of service must have in order to meet consumer needs, against on how consumers perceive the actual mall performance in the context of what they expected to ensur of good service to classify into three categories of factors: Basic, Performance and Excitement.The findings of this study may prompt future research to create a new tool to help those managers and service companies in the process of making decisions aimed at improving the strategic relationship with retail companies and thus to improve the quality of the mall services. One contribution of this study is the simple proposed model used to understanding how quality processes affect each organizational dimension of service performance.

Keywords: Quality Management; Shopping Center; Service Quality; SERVQUAL; Service Dimensions. 


\section{INTRODUCTION}

Customer satisfaction measurement involves many aspects; the most important is the collection of data that provides information about the satisfaction or dissatisfaction of a service on the customer view. Customer satisfaction measurement enable an organization to better understand which factors and attributes of the service that driving and influences the customer most during a service experience. And which factors and attributes are outside of the organizational control.

In this sense, this paper proposes a new way for evaluating the customer satisfaction. We use malls built in Brazil as a case of study, to guarantee the efficiency of the proposed model. In Brazil there are 495 malls, 52\% of them are located in the state capitals. Together they employ 843.254 people, there are 415 million visits per month, and generate $R \$ 129$ billion in revenue per year, according to the Brazilian Association of Shopping Centers (ABRASCE, 2013).

Service literature has focused largely on financial measurement, rather than societal outcomes. Our study builds on this work by investigating the effect that service quality management can influence the consumer satisfaction in multidimensional criteria of the environment. Using these insights, managers can determine which service quality dimension most influences customer happiness, and then develop strategies to focus on this dimension. The quality characteristic or dimension that are important to the customer, depend on his/her subjective and emotional factors. Such efforts offer advantages to customers (e.g. positive effect on consumer well-being and customer's satisfaction), and society at large (greater overall trademark loyalty).

A unified view of quality can be defined as the degree of customer expectations and the perceptions of the service performance provided. It comes from the subjective experience of each customer boarded as inter-personal and as service interactions, and it is generally examined as global perceptions of the adequacy of the strategy of services. In the same way, the strategy of services should be geared to the customer's real priorities (Baker, 2006; Kunz et Hogreve, 2011).

\section{SCENARIO AND THE MANAGEMENT OF THE MALLS}

Along the years, Shopping mall adapting, in terms of their design but also of their internal structure, as the requirements of their users. Nowadays it is common to find clinics and doctor's offices, laboratories, universities and other no-related selling activities. These non selling activities generate a particular flow of people on days and at times that do not compete with the peaks of traditional stores, e.g. Christmas and Valentine's day.
The higher level of the consumer needs and the increase competition create a field to design and implement appropriate mechanisms for assessing the quality of service on the malls (Berman, 2005). The most noticed attribute in the mall is the physical or tangible, it is related to the modern, comfortable, accessible infrastructure. It also refers to the image given to the costumer and also to the service provided among their current and potential mall competitors. But, others attributes can stimulate the quality on the interactions with a service provider and customer, such as: Reliability, Responsiveness, Assurance, Empathy (Parasuraman, 1985). We can associate these attributes as a functional quality. It entails the way of how the technical quality gets transferred to the customer. It also can be related to the satisfaction that the customer feels toward the process or experience of the service giving. Grönroos (1990) stresses the importance attributed to the corporate image, because in most cases, customer can actively interact when the service has been done. This co-operate action may generate positive (satisfaction) and negative impacts (rejection, frustration); it depends on the practical and technical skills and on these attributes.

\section{MEASUREMENT OF THE SERVICE MALL}

One model of service measurement is the SERVQUAL (Parasuraman, 1985). It has been used in different service sector, such as: banks, credit card companies, electronic, insurance, hospital and higher education services.

This model gives a holistic view of quality to the enterprise, and it can be defined as the customer judgment between expectations and the perceptions of the service developed, on five dimensions of service attributes: Reliability, Responsiveness, Assurance, Empathy and Tangibles.

This model stands out the concept that quality is fitness to use. There are three possibilities for the comparison: (i) Expectations < Perceptions: the quality perceived is good; (ii) Perceptions = Expectations: the quality perceived is acceptable; and, (iii) Expectations > Perceptions: quality is not perceived. The result of comparing expectations and the perceptions is described on these gaps: Gap 1: represents the difference between customer' expectations and management's perceptions of customer' expectations; Gap 2: represents the difference between the perceptions that management has of customer' expectations and the specifications of service quality; Gap 3: represents the difference between service quality specifications and service delivery; Gap 4: represents the difference between the service rendered and external communication with clients (promise); Gap 5: represents the difference between the service expected and the service received. But the extent to which the peculiarities of services provided fit into the SERVQUAL scale should also be considered in the assessment. 
We choose this model because it is simple to survey the customer and to analyze the data by the managers. The most fundamental effects that the managers should consider are what service is and what vision it has about their customers. With this information, they can define how and what part of the service is relevant according to the customer view; it will provide helpful information to differentiate the organization among their competitors.

\section{PROPOSED MODEL OF MALL MEASUREMENT}

In the proposed model, we considered the customer expectation to be a very important parameter to use as a guide on the assessments of the mall service quality. We use the expectations measurement in order to reduce the gaps by improving the quality of service that is essential for the development the mall. Based on this, we use the Gap 1 and the Gap 5 to balance the trade-off between the target public expectations and the new services offers by the mall.

In others words, it is essential to understand which features and level of service must have in order to meet consumer needs (Gap 1), against on how consumers perceive the actual mall performance in the context of what they expected to ensuring good service (Gap 5). According to this difference of customer and manager view, we can classify the five dimensions into three categories proposed by Matzler et Sauerwein (2002): 1. Basic factors: minimum requirements in a service to prevent the customer from being dissatisfied. They do not necessarily cause satisfaction but conduct to dissatisfaction if absent; 2 . Performance factors: the factors that lead to satisfaction if realized and can lead to dissatisfaction if not fulfilled (e.g. reliability); 3. Excitement factors: the factors that increase customers' satisfaction if realized but does not cause dissatisfaction if not fulfilled. In this sense, the managers must focus the factor 3 , to prompt the mall image to offer a good quality in their service.

\section{METHODOLOGY}

The study is qualitative and takes a descriptive approach. It was conducted in two stages: first we collected the customer judgments drift by SERVQUAL questionnaire of a mall and after we analyzed with statistical technique of factorial analysis this data obtained.

SERVQUAL questionnaire (Appendix 1) has 22 questions that cover all five quality service dimension analyses, divided as follow: tangible aspects (questions 1-4); empathy (5-10); assurance (11-14); responsiveness (15-17); and reliability (18-22). Each question requires to the respondents their judgment about their degree of agreement or disagreement of the service expectation and performance (ANDERSON et al., 2009). Likert scale was used to express this degree; we used ranges from 1 that means "I strongly disagree" to 7 that means "I strongly agree". After the 22 responses, we calculate the average of the sum of each dimension. The scores that are achieved in customer satisfaction surveys from the questionnaire are used to create a customer satisfaction index. A definition of what comprises a customer satisfaction index is based on Parasuraman (1985). We use an average of the two key measurements defined by the SERVQUAL (an indication of how satisfaction or dissatisfaction is). The next step is to range each value into three categories proposed by Matzler et Sauerwein (2002). As a guide, the interpretation can be made of scores of the degree, from many different customer satisfaction views, as described at Table 1.

Table 1. Categories of service classification

\begin{tabular}{|l|l|l|}
\hline \multirow{2}{*}{ Factors } & \multicolumn{2}{c|}{ Overall Classification } \\
\cline { 2 - 3 } & Satisfaction & Dissatisfaction \\
\hline Basic & $>3$ & $>2,5$ and $<3,5$ \\
\hline Performance & $>5+$ & $>4,5$ and $<3$ \\
\hline Excitement & $>6,5$ and $<7$ & $>5,5$ and $<6,5$ \\
\hline
\end{tabular}

Overall rating measures are questions where customers are asked to rate various aspects of the service (e.g. telephone call handling, the application process etc) and their experience of the service as a whole. These questions generally use a rating scale of one type or other to summaries the customer's perceptions or feelings about a service or aspects of it. While there has been much debate within the research community about which scales work best in customer satisfaction measurement, there is no universally 'accepted wisdom' in this area.

In others words, overall measures provide a snapshot of how the service and its specific components have been doing during the "truth customer moment".

\subsection{Characteristics of the shopping center case of study the list}

The mall in this case study is classified as a regional Shopping Center, according to the typology of the International Council of Shopping Centers (ICSC, 1999). The mall has 220 shops, generates about 4,000 direct jobs and receives an average of 45.000 guests per day, or more than 14.6 million consumers each year. The total sale, in the fiscal year of 2002, corresponding an amount of $\$ 153$ million. It was opened in 1993, since that time, the mall upgrading its infrastructure in areas like: entertainment, food court and parking.

\section{ANALYSIS OF THE RESULTS}

The survey data are composed by 68 managers of stores at the mall case of study. These managers represent the first level of mall customer; they are directly influenced and affected by the CEO mall decisions. We chose the managers to confront what they need to improve in their business and what are the issues or strategies given to the CEO mall to 
established the attitude of interest in this type of service among guest customers.

The data of customer survey has the following characteristics: $65 \%$ are male, $73 \%$ of the respondents are managers and business owners; $61.3 \%$ of them had been working in the mall more than five years; $26.5 \%$ of them had been working in the mall, less than five years until two years; $13.2 \%$ of them opened a store recently, less than two years ago.

The analysis of Gap 1 revealed the difference between customer expectations and CEO mall perceptions. In the data have more negative statements than positives, only five results were positive: questions 15 and 17 from the dimension of responsiveness and questions 19, 20 and 21 from the dimension of reliability.

Overall, the perception of the administration did not match with its customer expectations, which means that together, they do not have a positive view, see the best results on the Appendix 1, such as: Service providers should be in one location $(-2,49)$, The administration gives clients individual attention $(-1,11)$, Administration managers are courteous $(-1,04)$. It shows the tremendous discrepancy between what the administration thinks that the customer considers important and what the customer really considers to be. We observed that the CEO mall statements related to the assurance dimension have the highest judgment value of 6.83 points of average and the dimension of responsiveness have the lowest average of 6.53. In opposite view, the customer judgment shows that reliability has the highest value of 6.98 and responsiveness is the second important dimension with sum of 6,59 points, next comes the empathy $(6,29)$, assurance $(5,94)$ and last important dimension is tangible with average of 5,39 points. But, if we analyze closer, the reliability dimension has the minimum difference of customer and CEO mall view of 0,136 points in average. Responsiveness dimension was good evaluated by the customer, and the difference on average is 0,057 points.

We also evaluated the Gap 5 that shows the quality of the mall management and identify the strategies of CEO mall to attend their customers. The dimension of assurance is only one and had a positive assertion that links CEO mall and customer need. All results were negative, see Appendix 1; the expectation of customer was greater than the perception of CEO.

In the Table 2, we can observe the difference of service category according to customer and manager view. This means that the quality of service is not satisfactory when compared with users' expectations and perceptions, which means the need for the administration to draw up programs targeted exclusively on its customers who are the service provider. In this view, we can affirm that the administration is not listening to their clients, does not address their complaints. The communication between the customer and CEO mall administration fail. As we can observe, the lowest average quality of services in this Table 2 is related to the mall management, which is why the overall result is excitement dissatisfaction. The mall focus only to the guest customer and forgot the internal customer. These are the service provider, as we already know. If the mall takes care and listens to them, the most benefit with this attitude is the image of the Shopping Center case of study.

Table 2. Mall customer and manager service classification

\begin{tabular}{|l|c|c|c|c|c|}
\hline \multirow{2}{*}{ Dimensions } & Customer & GAP 1 & GAP 5 & & Overall \\
\cline { 3 - 4 } & View & $\begin{array}{c}\text { CEO } \\
\text { mall }\end{array}$ & $\begin{array}{c}\text { CEO } \\
\text { mall }\end{array}$ & Average & $\begin{array}{c}\text { Ovification } \\
\text { Classifinn }\end{array}$ \\
\hline Tangible & 5,393 & 6,325 & 3,735 & 5,151 & $\begin{array}{c}\text { Performance } \\
\text { Satisfaction }\end{array}$ \\
\hline Empathy & 6,29 & 6,867 & 4,35 & 5,836 & $\begin{array}{c}\text { Performance } \\
\text { Satisfaction }\end{array}$ \\
\hline Assurance & 5,938 & 6,825 & 4,74 & 5,8343 & $\begin{array}{c}\text { Performance } \\
\text { Satisfaction }\end{array}$ \\
\hline Responsiveness & 6,59 & 6,533 & 4,892 & 6,005 & $\begin{array}{c}\text { Excitement } \\
\text { Dissatisfaction }\end{array}$ \\
\hline Reliability & 6,856 & 6,68 & 4,892 & 6,1427 & $\begin{array}{c}\text { Excitement } \\
\text { Dissatisfaction }\end{array}$ \\
\hline \multicolumn{5}{|c|}{ Source: The authors own (2015) } \\
\hline
\end{tabular}

One of the simplest ways to solve this problem is the use of SERVQUAL methodology of analysis currently, which represents an effort to achieve the optimum value of a product or service by promoting the functions needed which are perceived as important for the consumer and which will imply reducing the administrative costs of the Shopping Center case study.

These measures are valuable in providing the insights that can lead to service transformation, to fill in the gaps of Dissatisfaction (Table 1).

Other point obtained from the measures, is the customer priorities, when we analyze and ask customers to rate the importance of service elements (see the SERQUAL questionnaire - Appendix 1 - the main measure of each aspect), to rank them in order of importance against each other aspect. Table 3 presents the customer ranking order of what they considered the most attribute of satisfaction during the service. The administration keeps its records updated, provides the right service the first time and promises to do something within a certain time limit. It does so are ranking as the most approached from the Parasuraman (1985) service quality definition: Perceptions $=$ Expectations.

However, while each of these seven aspects are well classified, they all have shortcomings, because customers can change their idea of what is quality according their preferences. Many reasons can conduct to change her or his mind from what aspects of service they need in the most and about their degree of agreement or disagreement of the service expectation and performance, for example: changes in their daily routine and mood; school, work and family pressure. 
Table 3. Mall customer rank order classification

\begin{tabular}{|c|c|c|c|}
\hline $\begin{array}{l}\text { Number } \\
\text { of } \\
\text { question }\end{array}$ & Question description & $\begin{array}{l}\text { Customer } \\
\text { view }\end{array}$ & $\begin{array}{l}\text { Rank } \\
\text { order }\end{array}$ \\
\hline 4 & $\begin{array}{l}\text { The material associated with the } \\
\text { service provided by management, such } \\
\text { as accounting, billing, is illuminating. }\end{array}$ & 6,81 & 60 \\
\hline 6 & $\begin{array}{l}\text { The administration shows interest in } \\
\text { resolving clients' complaints. }\end{array}$ & 6,88 & \\
\hline 17 & $\begin{array}{l}\text { The administration communicates to } \\
\text { clients exactly when services will be } \\
\text { completed. }\end{array}$ & 6,94 & 30 \\
\hline 18 & $\begin{array}{l}\text { The administration must demonstrate } \\
\text { that security procedures are reliable. }\end{array}$ & 6,9 & 40 \\
\hline 19 & $\begin{array}{l}\text { The administration keeps its records } \\
\text { updated. }\end{array}$ & 7 & 10 \\
\hline 20 & $\begin{array}{l}\text { The administration provides the right } \\
\text { service the first time. }\end{array}$ & 6,98 & 20 \\
\hline 21 & $\begin{array}{l}\text { When the administration promises to } \\
\text { do something within a certain time } \\
\text { limit it does so. }\end{array}$ & 6,98 & 20 \\
\hline
\end{tabular}

Other measure is the biggest attribute of dissatisfaction during the service, this will indicate which actions can be taken or implemented to adequate the service according the customer view. In this sample we get the question of Service providers should be in one location ( 3,85 points).

To bring the customer service standards to the service process, the organizational must design a customer services action plan. This will help to maintain the commitment of all employees involved, and will ensure if they are adequately trained according to the customer service focus. But, it is not a simply task, it complaints and ad-hoc suggestions, a strategic approach and another organizational culture based on the "Customer Service Focus" of striving for excellence on the service management. By introducing and maintaining processes, policies and working focused on the needs and interests of the customer.

An important point of these categories is service classification; the survey results can differentiate between 'hygiene service factors' that are expected as a basic standard (accurate information, being polite, responding in an adequate time, and others), factors that really drive satisfaction and factors that drive dissatisfaction. Because people have a tendency to rate good grade on all service elements, or rate them as being important. This technique overcomes this problem, but ranking the service into categories, it provides an accurate indication of the aspects of service delivery that really drive customer satisfaction.

Organizations can use customer satisfaction measurement to improve in service delivery continuously. "Customer Service Focus" gives customer insight opportunities to change what they really want to change. Not just to measure the impact of service, but to improve actions in the most attribute or aspects of dissatisfaction of the service. It allows an organization, for example the Shopping Center case study, to understand the issues, key drivers or nuclear aspects that cause satisfaction or dissatisfaction with their service experience. In this sense, any organization can focus its time and internal resources (employees, money, equipments, and others) more effectively. We designed a customer satisfaction classification to provide a robust scale of interpretation. The customer questionnaire data produced actionable findings, see Table 2 and the analysis of the results.

Once you have conducted the customer survey proposed at this paper on the findings of the research - Table 2 and 3 , this will improve the customer experience. On the other hand this survey must be re-applied to get the newest aspects of the customer needs, because he or she can change her mind of what is good and poor quality on the service provided.

Other important action is to communicate these findings in the organization; it will help to make a creative and workable plan of action. This plan will be implemented in near future to correct the aspects of dissatisfaction and to promote highest level on the satisfaction aspects, to approximate the maxima of Parasuraman (1985): Perceptions = Expectations, or to exceed Expectations - delighting the customer.

\section{CONCLUSIONS}

This article highlighted the importance of service as a strategic tool for competitiveness. And the data analysis confirms the potential of the model used in this study as a management tool to improve quality in the mall.

Among the statements that had the lowest averages (empathy and reliability) put the management on focus and CEO mall should take an interest in customer suggestions and complaints. It was found that the mall management needs to change to better adapt to customer's needs, changing their way of communicating with the service providers.

One contribution of our study is that it provides managers a very simple framework for understanding how quality processes affect each organizational dimension of service performance. This is useful on two different levels; first, it helps us to understand the linkages between strategies and practices/performance; and, it can be used to evaluate how different quality improvements are linked to customer satisfaction and business performance.

\section{REFERENCES}

ABRASCE, Brazilian Association of Shopping Centers (2011), Statistic of brazilian shopping center. Available via DIALOG, Available in: <http://www.portaldoshopping.com. br/numeros-do-setor/evolucao-do-setor $>$, Accessed: 25 Feb 2015

Anderson, J.; James, N.; Narayandas, D. (2009), Business market management. Pearson Education. 
Baker, S. M. (2006), Consumer normalcy: understanding the value of shopping through narratives of consumers with visual impairments, J Retailing.

Berman, B. (2005), How to delight your clients, California Management.

Grönroos, C. (1990), Service Management and Marketing. Lexington Books: Lexington, MA.

ICSC, International Council of Shopping Centers, Statistic of shopping center (1999), Available via DIALOG. Available in: <http://www.icsc.org/srch/lib/SCDefinitions99.pdf>, Accessed: 20 Feb 2015.

Kunz, W.; Hogreve, J. (2011), Toward a deeper understanding of service marketing: The past, the present, and the future. International Journal of Research in Marketing.

Matzler, K.; Sauerwein, E. (2002), The factor structure of customer satisfaction: an empirical test of the importance grid and the penalty-reward-contrast analysis, International Jornal of Service Industry Management.

Parasuraman, A.; Zeithaml, V. A.; Berry, L. L. (1985), A conceptual model of service quality and its implications for future research, Jornal of Marketing. 
APPENDIX 1

\begin{tabular}{|c|c|c|c|c|c|c|c|}
\hline & \multirow{2}{*}{$\begin{array}{l}\text { QUESTIONS OF SERVQUAL QUESTIONAIRE AND THEIR QUALITY } \\
\text { DIMENSIONS }\end{array}$} & \multicolumn{3}{|c|}{ GAP 1} & \multicolumn{3}{|c|}{ GAP 5} \\
\hline & & $\begin{array}{c}\text { a) } \\
\text { Customer }\end{array}$ & $\begin{array}{l}\text { b) CEO } \\
\text { mall }\end{array}$ & $\begin{array}{l}\text { Diference } \\
\text { of (a) - (b) }\end{array}$ & $\begin{array}{c}\text { a) } \\
\text { Customer }\end{array}$ & $\begin{array}{l}\text { b) CEO } \\
\text { mall }\end{array}$ & $\begin{array}{l}\text { Diference } \\
\text { of }(b)-(a)\end{array}$ \\
\hline \multicolumn{8}{|c|}{ Tangible aspects } \\
\hline 1 & Service providers should be in one location. & 3,85 & 6,3 & $-2,45$ & 3,85 & 4,34 & 0,49 \\
\hline 2 & $\begin{array}{l}\text { The administration should have advertising geared specifically to the } \\
\text { provision of services in the mall. }\end{array}$ & 5,56 & 6 & $-0,44$ & 5,56 & 2,17 & $-3,39$ \\
\hline 3 & Management invests in technological modernization. & 5,35 & 6 & $-0,65$ & 5,35 & 3,85 & $-1,5$ \\
\hline 4 & $\begin{array}{l}\text { The material associated with the service provided by management, } \\
\text { such as accounting, billing, is illuminating. }\end{array}$ & 6,81 & 7 & $-0,19$ & 6,81 & 4,58 & $-2,23$ \\
\hline \multicolumn{8}{|c|}{ Empathy } \\
\hline 5 & The administration's hours of operation are convenient for its clients & 6,29 & 6,8 & $-0,51$ & 6,29 & 4,35 & $-1,94$ \\
\hline 6 & The administration shows interest in resolving clients' complaints. & 6,88 & 7 & $-0,12$ & 6,88 & 4,46 & $-2,42$ \\
\hline 7 & The administration is interested in clients' suggestions. & 6,46 & 6,8 & $-0,34$ & 6,46 & 3,92 & $-2,54$ \\
\hline 8 & The administration understands clients' specific needs. & 5,75 & 7 & $-1,25$ & 5,75 & 4,02 & $-1,73$ \\
\hline 9 & The administration is focused on client. & 6,67 & 6,8 & $-0,13$ & 6,67 & 4,77 & $-1,9$ \\
\hline 10 & The administration gives clients individual attention. & 5,69 & 6,8 & $-1,11$ & 5,69 & 4,58 & $-1,11$ \\
\hline \multicolumn{8}{|c|}{ Assurance } \\
\hline 11 & Administration officials convey confidence. & 5,4 & 6,8 & $-1,4$ & 5,4 & 4,79 & $-0,61$ \\
\hline 12 & Clients feel secure in their dealings with administration officials. & 6,02 & 6,5 & $-0,48$ & 6,02 & 4,79 & $-1,23$ \\
\hline 13 & Administration managers are courteous. & 5,96 & 7 & $-1,04$ & 5,96 & 4,98 & $-0,98$ \\
\hline 14 & $\begin{array}{l}\text { Employees receive adequate support from management to perform } \\
\text { their tasks well. }\end{array}$ & 6,37 & 7 & $-0,63$ & 6,37 & 4,4 & $-1,97$ \\
\hline \multicolumn{8}{|c|}{ Responsiveness } \\
\hline 15 & The administration gives quick answers to clients' questions. & 6,37 & 5,8 & 0,57 & 6,37 & 4,56 & $-1,81$ \\
\hline 16 & The administration attends to clients promptly. & 6,46 & 7 & $-0,54$ & 6,46 & 4,73 & $-1,73$ \\
\hline 17 & $\begin{array}{l}\text { The administration communicates to clients exactly when services } \\
\text { will be completed. }\end{array}$ & 6,94 & 6,8 & 0,14 & 6,94 & 4,73 & $-2,21$ \\
\hline \multicolumn{8}{|c|}{ Reliability } \\
\hline 18 & $\begin{array}{l}\text { The administration must demonstrate that security procedures are } \\
\text { reliable. }\end{array}$ & 6,9 & 7 & $-0,1$ & 6,9 & 4,85 & $-2,05$ \\
\hline 19 & The administration keeps its records updated. & 7 & 7 & 0 & 7 & 5,13 & $-1,87$ \\
\hline 20 & The administration provides the right service the first time. & 6,98 & 6,3 & 0,68 & 6,98 & 4,73 & $-2,25$ \\
\hline 21 & $\begin{array}{l}\text { When the administration promises to do something within a certain } \\
\text { time limit, it does so. }\end{array}$ & 6,98 & 6,3 & 0,68 & 6,98 & 4,81 & $-2,17$ \\
\hline 22 & $\begin{array}{l}\text { The administration is at its most sympathetic and helpful when the } \\
\text { client service has issues. }\end{array}$ & 6,42 & 7 & $-0,58$ & 6,42 & 4,94 & $-1,48$ \\
\hline
\end{tabular}

